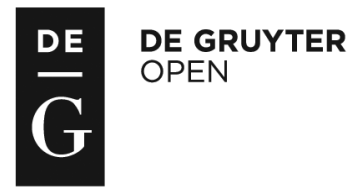

Administration, vol. 63, no. 1 (2015), pp. 41-70

doi: 10.1515/admin-2015-0005

\title{
The statistical treatment of government interventions in the banking sector during the financial crisis
}

\author{
Patrick Quill \\ Central Statistics Office
}

\section{Introduction}

In the last number of years and in the context of the financial crisis the Irish Government has been involved in a number of large interventions and rescue operations, with significant impact on the state finances. Some of the interventions have been complicated and without precedent both in character and magnitude. As the standard for reporting and compilation of government finances is within the national accounts framework, the Central Statistics Office (CSO) and Eurostat have been central to the interpretation of the rules regarding the treatment of these interventions. In fact some new methodologies have been specified by the Irish cases.

Because the treatment in the national accounts is not always obvious to the non-specialist, there is a need for a clear exposition of the interventions, as well as an explanation of how these are treated in the accounts and, in some cases, a rationale for the treatment. This paper aims to address these three needs: the main banking interventions by the Irish Government are documented, and the impact on the public finances and the accounting treatment are discussed and explained. 
The interventions with the banking sector in Ireland's case were of crucial relevance in the statistical context. In the period from 2009 to 2011 Ireland set up a new state agency to manage distressed assets with book value of over $€ 70$ billion, Ireland made a $€ 30.85$ billion capital payment in the form of promissory notes to financial institutions and Ireland recorded the highest ever government deficit in the EU.

The paper outlines these interventions, with specific emphasis on the statistical treatment. It builds on the details presented in a 2011 article by Mary Cussen and Mick Lucey on the same topic, and on the background note provided by the CSO to Eurostat in the context of the July 2011 capitalisations of Ireland's pillar banks (Eurostat, 2012a). The discussion is further supported by Eurostat guidance, including advice to member states, findings of dialogue visits and formal correspondence, which are published on the Eurostat website under its transparency policy for decisions on government deficit and debt.

\section{Outline of the paper}

To begin, some contextual background to deficit and debt statistics is presented. The main focus of the paper is Table 1, which details all government transactions with the banking sector from 2008 to 2014, with each transaction discussed in the numbered notes following the table. The details of Table 1 are aligned with the results of the tables for the financial crisis produced by the CSO in April 2015, and the paper concludes with a summary of the impact of the interventions on the government finances.

\section{Background and accounting standard}

\section{EU stability governance and ESA}

The convergence of fiscal policies under the Maastricht Treaty and the Stability and Growth Pact provided reference values for government deficit and debt ceilings of 3 per cent and 60 per cent of GDP, respectively. The EU adopted the European System of National and Regional Accounts (ESA) as the framework for computing these key aggregates (European Commission, 2013). In particular, Council Regulation 479/2009 on the application of the protocol of the excessive deficit procedure (EDP) legislates for the provision of data and sets out the parameters for this provision by reference to the ESA. 
The ESA is the accounting standard used by members of the EU in the preparation of their national accounts. It is consistent with the UN's System of National Accounts (European Communities et al., 2009). Under the above Council Regulation, the ESA is the legally binding conceptual reference framework for the EDP. In addition the Manual on Government Deficit and Debt (the Manual) is the result of collective work by country experts coordinated by Eurostat and assists in the application of the ESA for calculating government deficit and debt data. The Manual, which is routinely updated, is indispensable for statisticians compiling government finance statistics and provides an agreed position for many government transactions and activities (European Commission, 2014).

A key principle is that all member states prepare the accounts according to the same accounting rules for comparability purposes. In practice, the national statistics institute is given responsibility for decisions on the application of the rules, with Eurostat being the arbiter in cases of dispute. The principle of harmonisation of application of the rules was undermined when severe irregularities were discovered with regard to the Greek deficit and debt data, a problem that had been recognised as early as 2004 but was not addressed properly until the ECOFIN Council conclusion of November 2009 invited the Commission (Eurostat) to prepare a report on the quality of Greek fiscal statistics, which was published the following January (European Commission, 2010). Meanwhile, as well as emphasising the need for accurate, transparent and comparable reporting of fiscal data, the onset of the financial crisis led to new types of interventions and rescue operations for financial institutions.

Accordingly, it was clear that the ESA and the Manual presented incomplete guidance on the treatment of certain transactions of unprecedented magnitude and regarding new bodies set up in the context of the financial crisis. Eurostat responded quickly this time and issued particular guidance for interventions with the financial sector in July 2009 (Eurostat, 2009a). The evolving nature of the interventions continued to be a challenge for national statisticians, and there have been a number of further Eurostat decisions and methodological advice to member states that have broadened the field of government finance statistics.

\section{ESA95 and ESA2010}

The national accounts are compiled in the EU according to the ESA framework. In 2014 the new ESA2010 standard replaced the previous 
ESA95 version and all EU member states were required to adopt ESA2010 by September 2014, on a retroactive basis. Details of the impact of the introduction to ESA2010 on the national accounts and Ireland's fiscal position are given in the CSO's July 2014 releases National Income and Expenditure Annual Results 2013 (CSO, 2014a) and Government Finance Statistics Quarterly Results, Quarter 12014 (CSO, 2014b).

For Ireland, the rules governing the treatment of governmentowned defeasance structures were re-examined with the introduction of ESA2010. (Defeasance is the management of problematic assets held by a financial institution, with significant negative impact on its profitability and its solvency.) Indeed, it was agreed by the CSO and Eurostat that the Irish Bank Resolution Corporation (IBRC) be classified in the general government sector with effect from mid 2011. A letter from Eurostat confirmed their position (Eurostat, 2014). ${ }^{1}$ The reclassification made a substantial impact retroactively to Ireland's debt and deficit. Ireland recorded a debt of 108 per cent of GDP for 2011 in April 2012. Ireland's debt ratio at this time was the third highest in the EU after Greece (165 per cent) and Italy (120 per cent). Had the IBRC been classified in government then an additional 13 percentage points would have been added to Ireland's debt. It was therefore of key significance that the IBRC was classified outside government according to the accounting rules that prevailed at the time.

For historical consistency and relevance, the main data in Table 1, up to end-2012, are compiled under ESA95. The data relating to 2013 and 2014 are based on the accounting treatment introduced with ESA2010, because the annual results are compiled by the CSO for the EDP tables of the following year, and by September 2014 ESA2010 had been adopted. The details from Table 1 are also aligned with the tables for the financial crisis published in 2015, which were compiled under ESA2010 (see Table 5).

${ }^{1}$ Eurostat's interpretation of ESA2010 is disputed by the European Central Bank (ECB), which set the monetary financial institution (MFI) list. The ECB, in order to align their statistics with the MFI classification, have an interest in what belongs in the financial corporations sector. On the other hand, Eurostat, being the Commission body responsible for the compilation of European statistics, retains a prerogative to define each of the sector populations for statistical purposes. 


\section{Direct interventions between government and the financial sector}

This section details flows between general government and the financial sector in the context of the financial crisis. Table 1 is the core of the paper and is a valuable record of interactions between these two sectors of the Irish economy during this critical period. The transactions are separated in the columns between outflows and inflows of general government, and between financial and nonfinancial transactions. The impact on the deficit and the impact on the debt of each transaction are also given. The transactions are noted with numbered discussion in the paragraphs following. Some notes explain more than one item. For this reason the order of transactions within each year in the table may not represent the chronological sequence.

In the 'Account' column transactions involving the Exchequer, those involving the National Pensions Reserve Fund (NPRF) and promissory note transactions are distinguished. The distinction identifies which transactions impact the debt.

A financial transaction is one where there is an exchange of one financial asset (e.g. cash) for another of equal value (e.g. shares). Financial transactions have no impact on the deficit whereas nonfinancial transactions (e.g. interest payments) are deficit-impacting. For this reason governments are eager to see that capital injections are treated as financial transactions or 'equity injections'. However, when national statistics institutes are compiling the government finance statistics, they have to examine large payments from public to private institutions, irrespective of their classification in the domestic fiscal accounts.

To determine whether the transaction will be classified as financial or non-financial, the capital injection test is applied. This is discussed in detail in Chapter III of the Manual (European Commission, 2014). Straightforward cases include loans, preference shares and cases where there is some private investor participation. A large, infrequent 'something for nothing' transfer of wealth between government and a public or private corporation is called a capital transfer and is a nonfinancial transaction. In Table 1 all non-financial transactions impact the deficit, whether they are paid from/into the Exchequer account or the NPRF, or relate to the promissory note. Column E shows the deficit impact as the difference between the non-financial transactions (columns $\mathrm{C}$ and $\mathrm{A}$ ). 


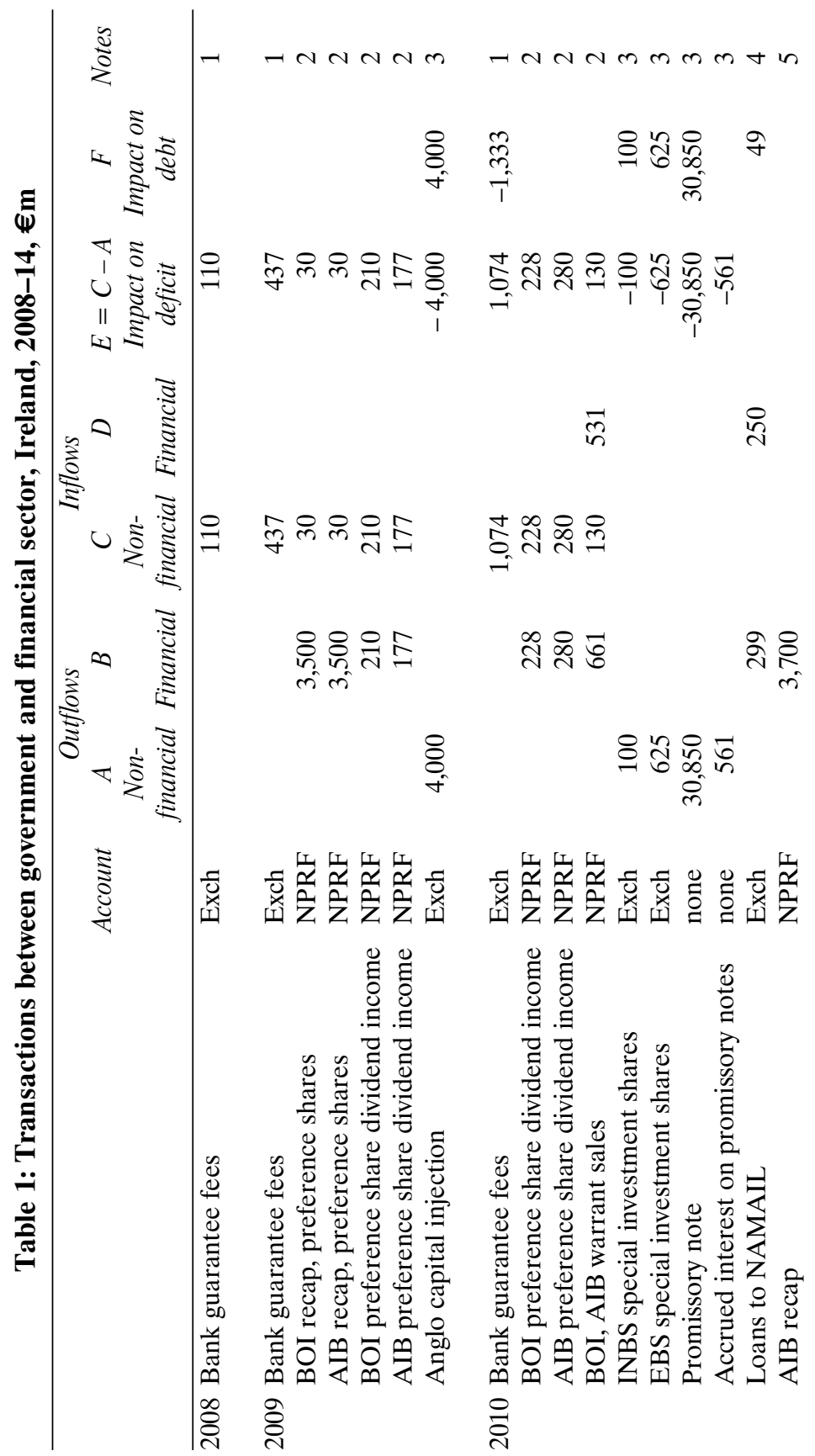




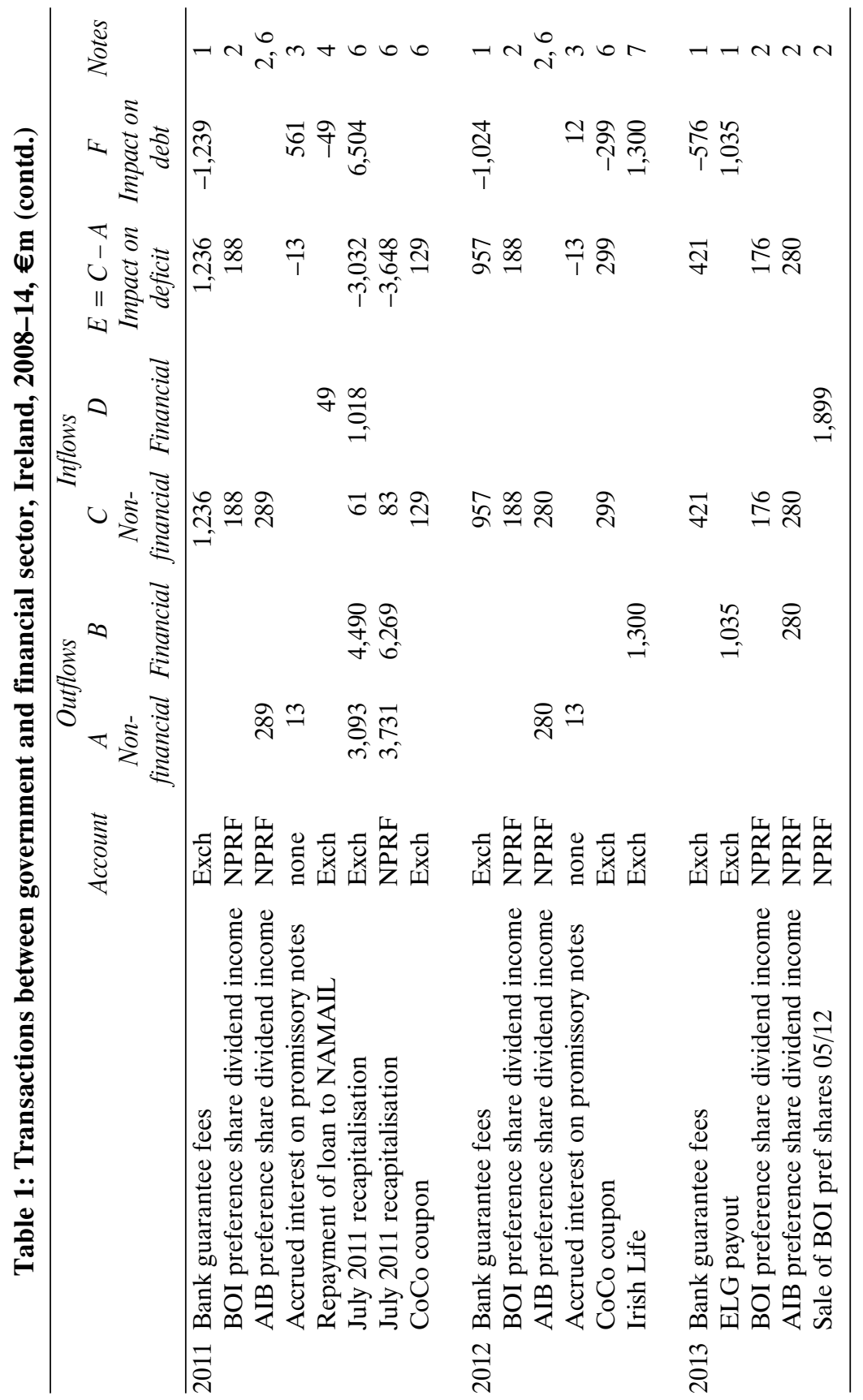




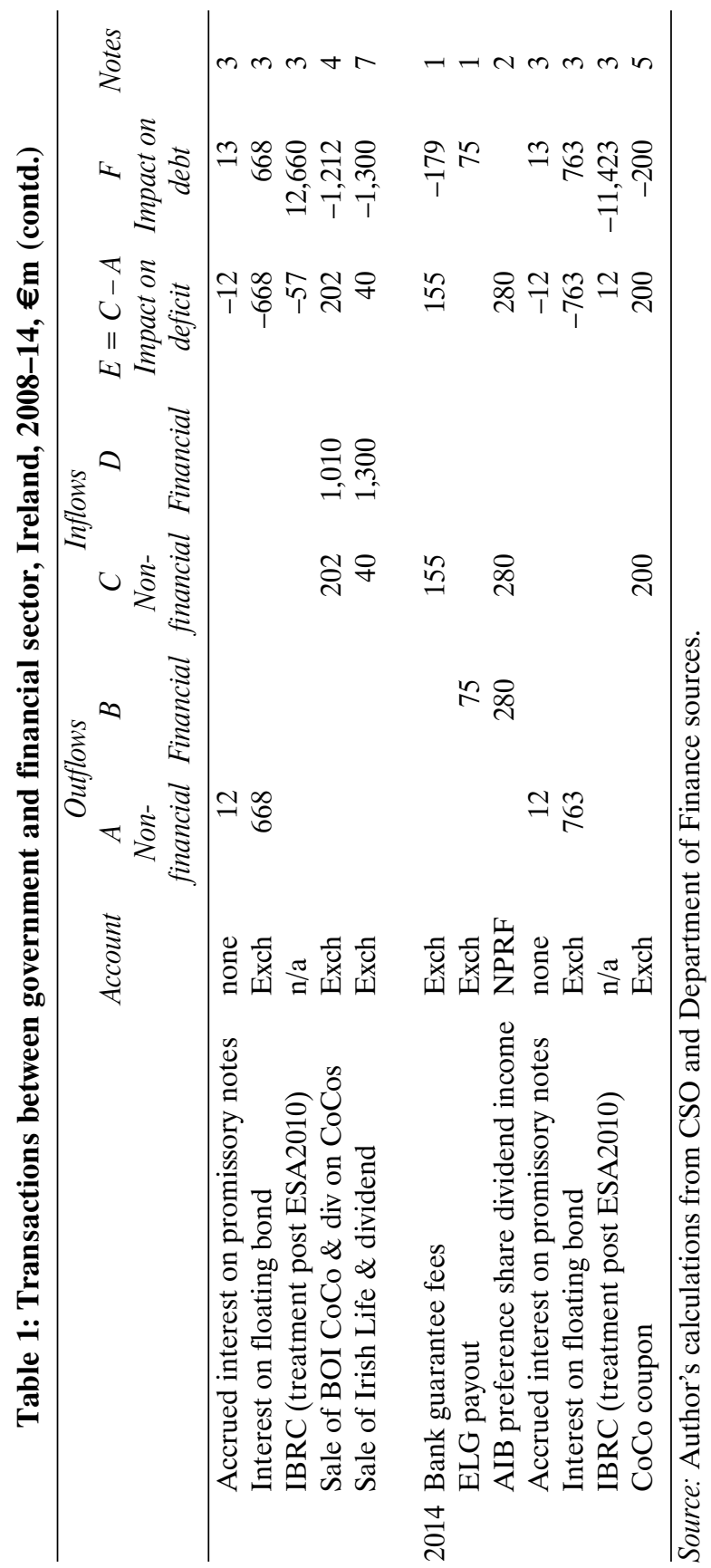


When cash is paid from or into the Exchequer account (also called the central fund), the payment increases the Exchequer borrowing requirement. By convention, such a transaction impacts the debt. On the other hand, many of the capital injections discussed here are paid from the NPRF. Although the NPRF is in general government, there is no impact on debt in this case. This is because no borrowing is necessary. The capital injection is made from funds already accumulated in the NPRF.

In summary, all non-financial transactions involving the Exchequer or the NPRF impact the deficit. All financial or non-financial transactions involving the Exchequer impact the debt. As the accrual principle is used, some payments affect the deficit and the debt at different times (see, for example, the discussion of bank guarantee fees below in Note 1).

Regarding signs $(+/-)$, a positive impact on the deficit implies a smaller deficit or an improvement to the deficit. A positive impact on the debt implies a larger debt.

\section{Notes on Table 1}

\section{Note 1: Bank guarantee fees}

The Credit Institutions Financial Support scheme was introduced from September 2008 for two years. The Eligible Liabilities Guarantee (ELG) scheme ran from December 2009 until March 2013. Under national accounting rules, guaranteed debt is a contingent liability of government and remains the debt of the corporation unless there is certainty that the guarantee will be called. In other words, there is no impact on the deficit or debt by the granting of a guarantee and the government can remain sanguine about the guarantee provided the likelihood of its being called remains small. The inflows shown in Table 1 represent fee income from the covered institutions. The first cash payments, impacting the debt, were made in 2010 but income accrued over the whole period from its introduction in 2008, impacting the deficit. Table 1 shows bank guarantee income for all years. From March 2013, no new liabilities are guaranteed, but fee income continues beyond March 2013 on existing guaranteed deposits. Cussen \& Lucey (2011) discuss the guarantee schemes in more detail.

When the IBRC was liquidated in 2013, there was a call on the guarantees relating to that institution. A total of $€ 1,035$ million was paid in cash in 2013 and $€ 75$ million in 2014. These data are presented as they are reported by the CSO since the introduction of ESA2010 in 2014. Under this treatment the IBRC is consolidated in general 
government. The payouts since 2013 are considered repayments of liabilities to creditors and classified as financial transactions, with zero impact on the deficit. These are paid from the Exchequer and impact the debt. The minister becomes an unsecured creditor through the payment to third parties of amounts due from the IBRC, and a significant amount of this payout is likely to be returned to the state.

It may be worth mentioning for historical reasons that during 2013 and until the introduction of ESA2010 in June 2014, the payouts were treated as deficit-impacting non-financial transactions. This was before the reclassification of the IBRC into government. The end2013 forecasts by the Department of Finance ${ }^{2}$ and impact assessments of the liquidation of the IBRC, as well as the EDP tables up to April 2014, were prepared on the basis that the IBRC was classified in the financial corporations sector. The relevance of this is that the deficit ratio was 0.65 percentage points worse at a time when Ireland was under troika surveillance with strict deficit targets.

\section{Note 2: 2009 preference shares}

\section{Preference shares}

In 2009 the NPRF Commission was directed by the Minister for Finance to invest in $€ 3.5$ billion preference shares of each of Bank of Ireland (BOI) and AIB. The direction for a total of $€ 7$ billion included also a warrant over ordinary shares of the banks. Fees of $€ 60$ million were received for the transaction. The preference shares pay an annual fixed dividend of 8 per cent that is to be paid in cash or in ordinary shares.

The preference shares have characteristics of a bond-like instrument. This is due to the commitment to make a fixed annual payment to the holder of the instrument. Although this payment is termed a dividend by the NPRF, it is treated as an interest payment, akin to a coupon, accruing evenly over the year. The capital injection is thus classified as a financial transaction, namely 'securities other than shares', with no impact on the deficit. As the payment is made from NPRF funds, there is no impact on the debt.

\section{Preference share dividends}

In 2010, following instruction by the EU competition authorities, the 'dividends' were paid in ordinary shares. As a consequence of the statistical classification of the preference shares, the following

2 The EDP tables prepared by the CSO contain a current year forecast of key aggregates. These forecasts are made by the Department of Finance. 
treatment applies when income is received in ordinary shares in lieu of cash. The interest/coupon due on the preference shares accrues evenly over the year. On the 'due for payment' date, it is assumed that the state reinvests the coupon amount into the banks. Thus, the payment of ordinary shares is rearranged into two payments: the receipt of interest, which is a deficit-improving non-financial transaction; and a capital injection by the NPRF into the bank, which must undergo the capital injection test. For this reason, when the preference share income was paid in ordinary shares, two entries appear in Table 1. Whether the outflow to AIB or BOI is treated as a financial transaction or not is based on the performance of the bank. This is discussed again in the context of the 2011 bank recapitalisations. The dividends for 2009 shown in the table represent amounts accrued up to 31 December of that year. All dividends from AIB have been paid in ordinary shares; the dividends from BOI since 2011 have been paid in cash.

\section{Preference share developments, 2010}

In April 2010 the NPRF converted $€ 1,036$ million of BOI preference shares into ordinary shares, at a cost of $€ 1.80$ per share, and subscribed to a further $€ 627$ million of ordinary shares at a cost of $€ 0.55 \mathrm{~m}$ per share (see Table 2). The latter transaction, also paid through the conversion of preference shares, was part of a BOI rights issue, which the NPRF is entitled to in consideration of the $€ 1,036$ million of ordinary shares already purchased. The coupon on the remaining 1,837 million preference shares increased from 8 per cent to 10.25 per cent. ${ }^{3}$

When the NPRF acquired the preference shares in 2009, warrants over ordinary shares in the banks were also issued. The warrants gave the NPRF an option to buy in the future up to 25 per cent of share capital at fixed prices. In 2010 BOI and AIB repurchased these warrants from the NPRF for $€ 479$ million and $€ 53$ million, respectively. Fee income related to these transactions amounted to a further $€ 130$ million. In 2010 the proceeds from the sale, as well as fees paid to the NPRF to each of the banks, were transferred to the discretionary investments of the NPRF. The income from the sale of warrants and the reinvestment of the income were treated as financial transactions. The fee income from the banks related to the sale did, however, improve the deficit. In 2014 the reinvestment of $€ 118$ million into AIB was reclassified as a non-financial transaction (see Table 6).

${ }^{3}$ See p. 52 of NPRF (2010). 


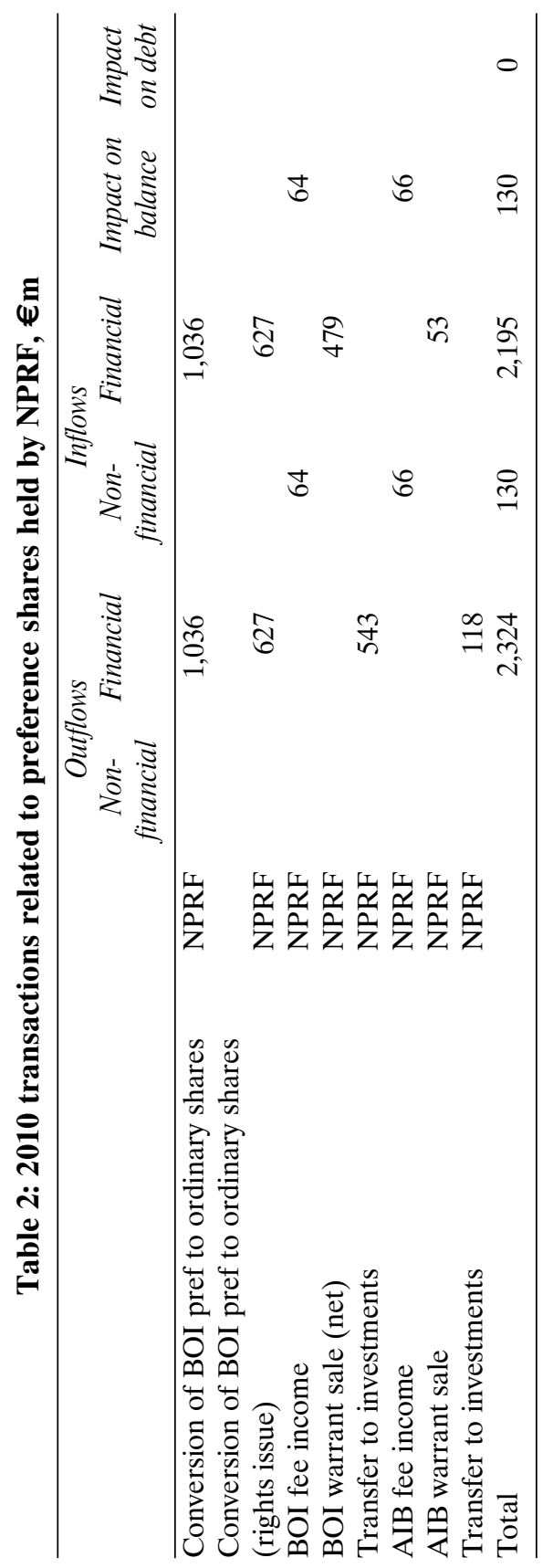


In December 2013 BOI bought back the preference shares. The state made a profit of $€ 62$ million on the sale, which did not impact the deficit as the profit was due to valuation changes in the stock of shares.

\section{Note 3: The IBRC and EBS}

The IBRC is the name given to the entity formed in June 2011 by the merger of the, by then, state-owned Anglo Irish Bank (Anglo) and Irish Nationwide Building Society (INBS).

\section{Cash injections in 2009 and 2010}

Between June and September 2009, a series of injections totalling $€ 4$ billion, or 2.5 per cent of GDP, was made into Anglo to protect its capital position. The October 2009 EDP notification for Ireland showed a current year deficit forecast of 12.0 per cent of GDP. Table $2 \mathrm{a}$ of this notification illustrates that the computation of the deficit excluded the capital injection into Anglo. 4 The 12 per cent deficit therefore illustrates the distressed position of Ireland's underlying finances in 2009. Meanwhile, the April 2010 EDP notification revised the treatment of the $€ 4$ billion injection into Anglo and reclassified it as a deficit-increasing capital transfer. Ireland reported the highest deficit in the EU for 2009 at 14.3 per cent of GDP.

In June and December 2010 the Educational Building Society (EBS) received $€ 625$ million from the Exchequer. The latter payment was footnoted in the Finance Accounts: 'the EBS issued 625 million perpetual special investment shares to the Minister for Finance between May and December 2010 for an aggregate subscription price of $€ 625$ million' (Government of Ireland, 2010). Despite this interpretation, the transaction was classified as a deficit-impacting capital transfer. This is a straightforward case where the statistical authorities judge that the payment is 'something for nothing'. Moreover, as the payment was made through the Exchequer, it was also debt-worsening. Alongside these payments, the state made a deficit-impacting cash injection of $€ 100$ million into INBS in 2010.

In summary, the state made a combined cash injection of $€ 4,725$ million into Anglo, INBS and EBS in 2009 and 2010. These injections were recorded as capital transfers with an impact on the deficit. The payments were made from the Exchequer and impacted the debt by the same amount.

4 The archived EDP notification tables are available on the 'Government Finance Statistics' section of the Eurostat website (ec.europa.eu). 
Promissory note injections in 2010

During 2010, six separate promissory notes were issued to Anglo and INBS, totalling $€ 25,300$ million and $€ 5,300$ million, respectively. The promissory notes were issued in lieu of cash, but were treated, for deficit purposes, as if the full payment was made in cash. The repayment structure of the promissory notes is akin to an amortising loan and for this reason the full amount added to the debt in 2010. There was a further promissory note of $€ 250$ million issued to the EBS. The total promissory note payment was thus $€ 30,850$ million.

The impact of the promissory note payment on the accounts of 2010 was truly devastating, adding 20 per cent to Ireland's deficit and debt. The 2010 deficit of 31.3 per cent of GDP (reported in October 2011) is the highest deficit recorded by any EU country since the start of the EDP process in 2003. Strikingly, Ireland's general government debt in 2009 was not much above the EDP ceiling, at 64.8 per cent of GDP, whereas in 2010 the general government debt soared to an alarming 91.2 per cent.

\section{Treatment of interest on the promissory notes}

The annual repayments of the promissory notes on 31 March have an interest and capital component. However, Eurostat accepted the concept of an interest holiday for the promissory notes of Anglo and INBS in the government finances for 2011 and 2012, where zero interest was to be paid. The decision rested on the application of a paragraph in the Manual referring to instruments with grace periods, which was designed for cases of government granting loans but was applied in this instance where the government was the borrower. See Cussen \& Lucey (2011) and Eurostat (2010) for a discussion of the interest holiday.

The details of the IBRC promissory note debt outstanding and the impacts on the deficit for 2010 to 2012 are shown in Table 3 . The table runs to 2012 as the promissory note was cancelled in 2013. A full schedule of proposed payments out to 2031, showing the debt outstanding and the deficit impacts, is given in Tables $4 \mathrm{a}$ and $4 \mathrm{~b}$ of the annex to the Medium Term Fiscal Statement (Department of Finance, 2012).

The EBS promissory note has no interest holiday and interest amounts of $€ 13$ million, $€ 13$ million, $€ 12$ millon and $€ 12$ million were payable for the years 2011, 2012, 2013 and 2014, respectively.

By convention, cash payments made on the promissory note have no impact on the government debt, because it is assumed that 
Table 3: IBRC promissory notes, interest, capital and debt outstanding, $€$ m (ESA95)

\begin{tabular}{|c|c|c|c|c|c|c|c|}
\hline Year & $\begin{array}{c}\text { Initial } \\
\text { prom } \\
\text { note } \\
a\end{array}$ & $\begin{array}{c}\text { Accrued } \\
\text { interest }\end{array}$ & $\begin{array}{c}\text { Cash } \\
\text { payment }\end{array}$ & $\begin{array}{c}\text { Of which } \\
\text { interest }\end{array}$ & $\begin{array}{l}\text { Capital } \\
\text { paid } \\
e=c-d\end{array}$ & $\begin{array}{c}\text { Impact } \\
\text { on deficit } \\
f=-(a+b)\end{array}$ & $\begin{array}{c}\text { Prom note } \\
\text { debt } \\
\text { outstanding } \\
g\end{array}$ \\
\hline 2010 & 30,600 & 554 & - & - & - & $-31,154$ & 30,600 \\
\hline 2011 & & - & 3,060 & 554 & 2,506 & - & 28,094 \\
\hline 2012 & & - & 3,060 & 0 & 3,060 & - & 25,034 \\
\hline
\end{tabular}

Source: CSO.

borrowing is needed to make the payment. The 2012 promissory note payment was made with a government bond. Although this mechanism avoided running down cash assets, it had the same impact on the accounts. Further details of this particular payment relating to the cost of borrowing can be found in Dáil Éireann (2012).

\section{Liquidation of the IBRC}

At the time of the liquidation of the IBRC on 7 February 2013, the IBRC was classified outside the government sector. There was no immediate impact on government debt as a result of the liquidation and the cancellation of the promissory note. The full amount of government debt outstanding in the form of promissory notes was replaced by the new floating rate bonds. However, the switch from promissory notes to government bonds implied that the cost of intervention in the IBRC was now included in the national debt (where previously the promissory note, being a commitment to pay certain future amounts, was a component of government debt, but not national debt), and interest was paid through the Exchequer account as part of national debt interest.

The interest rate on the bonds was much lower in the initial years than was payable on the promissory notes, and this made the cancellation of the promissory notes attractive to the Irish Government. The interest charged on the floating rate bonds was based on the six-month Euribor interest rate plus a fixed margin averaging 2.63 percentage points across the different issuances (see National Treasury Management Agency, 2014). The data in Table 1 relating to the floating rate bonds for 2013 were sourced from the annual report of the Central Bank of Ireland (2014). As the 2014 amount is not currently available, the value in 2014 was estimated. 


\section{The IBRC under ESA 2010}

With the introduction of ESA 2010 the IBRC was reclassified in government with effect from July 2011. The main impact has been on the debt where, although the promissory note liability of government is now consolidated with assets on the IBRC's balance sheet, the liabilities of the IBRC are now included as liabilities of government. The impact on the deficit is measured as the net lending/borrowing of the IBRC. The impacts on the debt and deficit are shown in Table 4.

\section{Table 4: Impact on the deficit and debt through reclassification of IBRC in 2014}

\begin{tabular}{|c|c|c|c|c|}
\hline & \multicolumn{2}{|c|}{ Impact on deficit ${ }^{1}$} & \multicolumn{2}{|c|}{ Impact on debt ${ }^{2}$} \\
\hline & $€ m$ & $\%$ of $G D P^{3}$ & $€ m$ & $\%$ of $G D P^{3}$ \\
\hline 2011 & -389 & -0.2 & $+20,927$ & +12.2 \\
\hline 2012 & -761 & -0.4 & $+17,797$ & +10.3 \\
\hline
\end{tabular}

Source: CSO.

Notes: $1 .-$ implies deficit is worsened in period.

2. + implies debt increase.

3. Per cent of GDP, as reported in CSO (2015).

The IBRC is treated as a non-market public financial corporation. Under this treatment its deficit in 2011 and 2012 was added to the deficit of general government. Similarly the outstanding debt of the IBRC was added to government debt. General government debt does not include liabilities of one government body which are assets of another. For this reason, the promissory note obligation from central government to the IBRC was consolidated. The 2011 and 2012 impacts in Table 4 can be added to the results in Table 1 to arrive at a presentation of events under the later treatment. The reclassification does not apply for years before 2011 and the results in Table 1 for 2013 and 2014 are already presented under the treatment adopted with the introduction of ESA 2010.

Note that the 2013 debt entry in Table 1 of $€ 12,660$ million represents the impact of including IBRC at end-2013 and is not to be accumulated with the end-2012 position from Table 4. The corresponding 2014 entry in Table 1, which is negative, reflects the reduction of liabilities to NAMA through the sale by IBRC in liquidation of loan asset during the year. 


\section{Note 4: Loans to NAMAIL}

Background to NAMA and classification issues

The National Asset Management Agency Act of 22 November 2009 provided for the establishment of the National Asset Management Agency (NAMA), which is classified in general government. The National Asset Management Agency Investment Limited (NAMAIL), a group entity of NAMA, was set up to purchase and manage assets from other financial institutions. NAMAIL purchased $€ 71$ billion worth of assets for a value of $€ 30$ billion. The end-2010 group balance sheet of NAMA showed these assets were matched by liabilities of which $c . € 29$ billion were debt securities, i.e. NAMA bonds guaranteed by government. The NAMA bonds are assets on the balance sheets of the participating institutions.

In the Supplementary Budget speech in April 2009, the minister, announcing the establishment of NAMA, stated that, as the assets were to be purchased with government bonds, this would add significantly to the national debt. It transpired that NAMA was able to be structured in such a way that the loans held by NAMA do not add to the government debt. This was done by designing the special purpose subsidiary NAMAIL. Had NAMAIL been classified in the general government sector then its liabilities would have added approximately 18 percentage points to the debt. The deficit may have also been affected through an increase in government expenditure (i.e. capital formation). 5

The methodological ruling which permits NAMAIL to be classified outside government was given in a Eurostat decision of 15 July 2009. In this note a decision for the classification of certain bodies outside government was made that was contrary to the usual guidance by placing ownership ahead of control.

'Majority privately owned special-purpose entities which are established with a short temporary duration and have a sole purpose to address the financial crisis, even if they receive a government guarantee, are to be recorded outside the general government sector if the expected losses that they will bear are small in comparison with the total size of their liabilities' (Eurostat, 2009a).

\footnotetext{
${ }^{5}$ See Cussen \& Lucey (2011), where the treatment is discussed by way of an example showing how the transfer affects the deficit. The treatment, however, is not certain. The acquisitions may have been viewed to be taking place in the context of debt assumption, in which case there is no impact on the deficit, as in the guidance in the Manual (European Commission, 2014, VII.2.3.3).
} 
Eurostat confirmed the statistical classification of NAMA and NAMAIL in their preliminary advice to the Irish authorities (Eurostat, 2009b). However, NAMA requires close monitoring by the $\mathrm{CSO}$ and Eurostat to confirm that the rules are not breached. In fact there was concern in March 2012 when one of the initial three private beneficial owners of NAMAIL - Irish Life - entered public ownership following a capital injection by the Irish Government in 2011. At the time, there was already a sale process underway to a private buyer. ${ }^{6}$ Nevertheless, Eurostat expressed dissatisfaction with the situation by placing a specific reservation on the reported Irish EDP data.

Thus, the statistical authorities treat the share ownership of NAMAIL very seriously despite the disproportionate value of the shares in comparison with the scale of assets and liabilities. In the dialogue visit of 2012 Eurostat also showed concern about whether a dividend is paid to the shareholders irrespective of the performance of NAMA (Eurostat, 2013a). The main issue, however, is that the expected losses that NAMA will bear are small in comparison with the total size of its liabilities.

Further classification issues arose in 2013 when, as part of the complicated choreography of the liquidation of the IBRC, NAMAIL exchanged $€ 12.9$ billion of NAMA bonds for a facility deed held by the IBRC. This was to be a short-term arrangement, which was to be replaced by the stock of unsold loan assets at fair value plus the difference made up in cash when the valuation and sale processes of the IBRC loan assets completed in 2014. In fact all the IBRC assets were sold so that the NAMA bonds were redeemed in full in cash during 2014. From a statistical point of view, some issues regarding the liquidation were that NAMA was not likely to lose on the exchange and whether the direction given by the minister was problematic. The first issue was solved by the actual successful outcome of the sales process. The second issue is at the heart of the 2009 guidance. It may be preferable to see no ministerial influence if it is claimed that the entity is private. But, as stated above, it is ownership that determines NAMAIL's sector classification, and not control.

6 Three private investors in NAMA hold a combined share value of $€ 51$ million, with the state holding $€ 49$ million in shares. The shareholders are entitled to a dividend payment on their investment. If NAMA is profitable there is a ceiling on how much the private investors stand to gain. On the other hand, if NAMA incurs losses the shareholders stand to lose their investment. 
Loans to NAMAIL

As a result of the classification of NAMAIL outside government, the flows relating to NAMA have very little impact on the deficit and debt. In 2010 the Exchequer made two payments to NAMAIL - $€ 49$ million in March and $€ 250$ millon in May - labelled acquisition in share capital and recoupable advance in the Exchequer statements. The latter advance was repaid in full in October of the same year, and the former was repaid in February 2011. These flows were treated as financial transactions.

\section{Note 5: Further capital injections into AIB}

In December 2010 AIB received a further capital injection of $€ 3.7$ billion. The payment was again made from the NPRF and did not impact the debt. At the time it was thought that this injection should be treated in the accounts as an investment or financial transaction and consequently did not impact the deficit. It was clear from the subsequent prudential capital assessment review (PCAR) exercise that there were significant capital requirements in the bank. This case was noted by Eurostat in advice to member states (Eurostat, 2012a). As a general rule, the accounts reflect the situation under a fair assessment at the time (see European Commission, 2014, III.2.2.3). In September 2014, however, the treatment was revised in the context of other improvements to the accounts brought in with the introduction to ESA2010. The injection was treated as a capital transfer, worsening the deficit for 2010 by approximately 2 per cent of GDP. Table 1 shows the contemporaneous treatment as was recorded in the EDP tables of 2011.

\section{Note 6: July 2011 recapitalisation}

In the first months of 2011 a major independent assessment of forecast losses under adverse conditions of Irish banks was conducted by BlackRock Solutions - the so-called 'stress tests'. There followed a PCAR to establish the extent of required capitalisation of the sector. Discussion of this process is given in Central Bank of Ireland (2011). In July 2011 Irish-owned banks were recapitalised in line with PCARspecified requirements (net of the liability management exercises conducted and the proposed disposal of Irish Life \& Permanent's (IL\&P) insurance arm). The extent of the capitalisation, details of beneficial banks and financial instruments are set out in Table 5. Significantly the table shows that there were net outflows of $€ 16,567$ million to three banks in 2011 . 


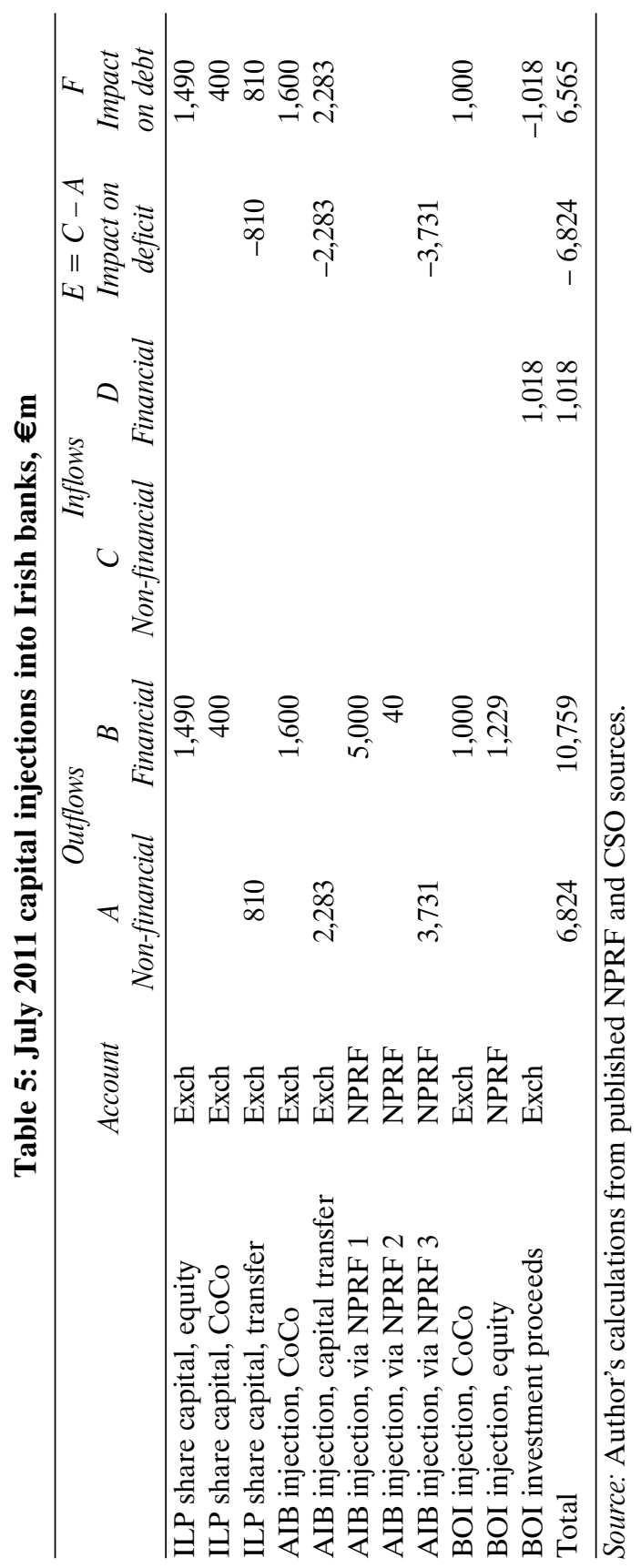




\section{Contingent capital notes}

$€ 3$ billion was paid to BOI and AIB in the form of contingent capital notes, which have a straightforward statistical treatment: these notes pay an annual coupon of 10 per cent, shown in Table 1 as a CoCo (contingent convertible) coupon. The notes were therefore treated as a financial transaction. Interest accrued for a half year in 2011 and further years, impacting the deficit, and cash payments from 2012 impacted the debt. In January 2013 the state sold its holding of BOI contingent capital notes at a profit of 1 per cent. The income on this sale was treated as a financial transaction with no impact on the deficit.

\section{Disposal of BOI shares and capital injections into BOI}

At the same time as the capital injections there was a $€ 1.018$ billion disposal of NPRF-held BOI shares to a consortium of North American investors. The proceeds of the share disposal were remitted from the NPRF to the Exchequer, improving the debt. Significantly, as a result of private sector co-investment, the full capital injection by the state into BOI can be treated as a financial transaction.

\section{Remainder of the July 2011 capital injections}

The treatment of the non-contingent capital part of the injection into AIB and IL\&P was based on a development of the capital injection test that sets out a novel way to assess large injections into financial corporations which are likely to suffer future losses.

The banks had accumulated significant losses up to this point. However, most of the losses had been absorbed in the first place by the original equity in the banks, and in AIB's case by the earlier injections by government. The capital injections were required therefore to absorb future losses and to achieve target capital requirement under PCAR of 10.5 per cent.

Under the guidance given in the Manual, in the situation where no private shareholders are investing, there are accumulated losses, but government makes a capital injection which exceeds the losses, then the transaction can be partitioned into non-financial up to the value of the losses and into financial for the remainder. The CSO proposed that this methodology be extended to cover future losses. The methodology looks forward rather than backwards, asking, 'How much would a rational investor be willing to pay for the assets acquired?' In other words, given that the state injects capital to absorb future losses, and that the banks will return to profitability and can be disposed of in 
the future, can a present value of the future sale price be estimated? This amount will be recorded as the remunerable portion of the injection, the remainder being a non-financial transaction.

The basis of this methodology is very reasonable within the context of the July 2011 capital injections. It is clear that the institutions are distressed and the government is unlikely to recover all of its funds. A sizeable part of the funds are required to meet capital requirements and there is an expectation that the banks will return to profitability. However, the methodology does present challenges for the statistician. There is uncertainty around the expected losses, and the point in time in the future chosen for the valuation is key to the outcome.

Both of these challenges are met again by the context. In Ireland's case, the injections into the banks were required to be overseen by the EU competition authorities. This exercise required detailed restructuring plans with four-to-five-year forecasts. The timescale used in the restructuring plans was satisfactory for statistical purposes and, as the process was documented for the approval of the European Commission under EU state aid rules, Eurostat was in a position to find the estimates reliable.

Based on this approach, an assessment of the value of the banks in 2015 and 2016 was taken from the restructuring plans, and it was estimated by the CSO that $€ 6,014$ million of the injection into AIB and $€ 810$ million of the injection into IL\&P were non-remunerable and thus classified as deficit-impacting capital transfers. Due to the novelty of the methodology, the CSO provided a detailed explanatory note, which was published on the Eurostat website (Eurostat, 2012a). ${ }^{7}$ Eurostat later incorporated part of the CSO methodology into the general guidance. In Eurostat (2012b), a business plan submitted to the competition authorities is considered 'indicative' in the capital injection test. Eurostat later alluded to subtleties to this approach (see Eurostat, 2013b).

\section{AIB preference shares reprise}

The AIB preference shares continue to be paid in ordinary shares for all years. As outlined above, the payment is rearranged into two transactions. The second transaction undergoes the capital injection test. In 2011 this transaction was combined with the July capital injections and was classified as a deficit-impacting capital transfer. For

7 The note was completed in March 2012 in advance of the final accounts for IL\&P. In fact, Eurostat signed off on the figures in October 2012 and so the final capital transfer quantum as presented here differs from that in the CSO note. 
subsequent years, the CSO adopted the following approach. The expectation of a return on this investment is connected to the 2011 capital injection into AIB. If the company can be shown to be meeting its business plan, then it is reasonable to inject further capital and expect a return. Eurostat's approach was to agree in principle with this analysis. However, rather than examine new restructuring plans or allow consideration of early losses so as to deleverage quickly, Eurostat adopts a strict adherence to the original restructuring plan. Measuring actual results against planned results, it can be observed if losses are covered by the July 2011 injections. As the AIB annual results for 2012 showed bottom-line losses greater than planned, the AIB preference share dividend did not benefit the accounts; but as the 2013 losses were not as large as in the restructuring plan, the 2013 preference share dividend was rearranged into a non-financial inflow plus a financial outflow benefiting the general government balance.

\section{Note 7: Purchase and resale of Irish Life}

The estimated capital requirement for IL\&P made in 2011 was $€ 4$ billion, of which $€ 1.3$ billion was to be raised through the sale to a private investor of the insurance arm of its business, Irish Life. When, during 2012, an expected sale did not materialise, the state was obliged to inject a further $€ 1.3$ billion into the bank. The minister took ownership of Irish Life until it was sold again in 2014. The capital injection and receipt after the resale were treated as financial transactions with no impact on the deficit but impacting the debt, and a dividend payment at the time of resale was treated as a deficitimproving non-financial transaction.

\section{Indirect impacts on the government finances and revisions}

Since 2009 Eurostat has requested member states to collect supplementary data on government interventions during the financial crisis. Eurostat publishes individual tables for each member state and a summary table with the aggregated data for the EU and the euro area. In this section the results from the previous section are aligned with the calculations of the impact on the deficit given in the financial crisis tables as published in April 2015. The tables - 'Impact of Banking Interventions on Deficit and Debt' - are retrievable in spreadsheet form from the 'Government Finance Statistics' section of the CSO website (www.cso.ie). The financial crisis tables include implied and imputed effects of financing government interventions as 
well as direct interventions. Thus, as well as acting as a check on the results outlined in the previous section, they provide a reference for defining indirect impacts on the government finances.

For each year between 2008 and 2014 imputed interest relating to flows to and from the Exchequer directly or indirectly associated with the financial crisis was calculated. An estimate of implied costs of the government guarantee was recorded as equal to the fee receivable under the same scheme. The implied cost lasted from 2008 until July 2011 when EU leaders agreed to reduce the interest rate and to extend the maturity on the EU loans provided to Ireland under the programme. The financial crisis tables further estimate what share of Central Bank dividend income since 2007 is attributable directly and indirectly to the financial crisis.

Table 6 sets out all the components of Part 1 of the tables for the financial crisis and aligns the results of this paper with the official tables. The direct effects were taken from column E of Table 1 of this paper; the impacts of imputed interest, implied interest and the increased Central Bank dividend income were sourced from the financial crisis tables; revisions to initial treatment of interventions were also included to bring the results in line with the latest version of the tables; and finally some one-off items not previously mentioned were included.

\section{Measuring the impact on the government finances}

As a conclusion to the paper, some often-asked questions about the quantum of the state's interventions with the banking sector during the financial crisis are addressed. The figure of $€ 64$ billion (see, for example, McArdle, 2012, or Barnes \& Smyth, 2013) is generally quoted as the total injection into Irish banks during the financial crisis. By taking into account both direct interventions and other indirect effects the validity of this assertion and other related questions are examined. It is acknowledged that there is an element of subjectivity to the interpretation of these questions, and for this reason the responses are discursive and outline what is understood by each question.

\section{What was the total amount paid into Irish banks during the financial crisis?}

Table 7 shows the payments (including the promissory note) into financial institutions over the period. The table includes all injections, 


\section{Table 6: Direct and indirect impacts on the deficit, revised treatments and other items related to the financial crisis, Ireland, 2008-14, €m}

\begin{tabular}{|c|c|c|c|c|c|c|c|}
\hline & 2008 & 2009 & 2010 & 2011 & 2012 & 2013 & 2014 \\
\hline \multicolumn{8}{|l|}{$\begin{array}{l}\text { Sum of direct } \\
\text { effects from }\end{array}$} \\
\hline Table 1, column E & 110 & $-3,116$ & $-30,424$ & $-5,139$ & 1,431 & 382 & -128 \\
\hline \multicolumn{8}{|l|}{ Indirect effects } \\
\hline Imputed interest & 0 & -214 & -259 & -536 & -662 & -622 & -584 \\
\hline Extra CBI income & 0 & 0 & 32 & 333 & 502 & 696 & 735 \\
\hline $\begin{array}{l}\text { Implied cost of } \\
\text { guarantee }\end{array}$ & -110 & -437 & $-1,074$ & -864 & 0 & 0 & 0 \\
\hline \multicolumn{8}{|l|}{ Revisions } \\
\hline $\begin{array}{l}\text { Reclassification } \\
\text { of IBRC } \\
\text { Revision of } \\
\text { treatment of } 2010\end{array}$ & 0 & 0 & 0 & -389 & -761 & $\mathrm{n} / \mathrm{a}$ & $\mathrm{n} / \mathrm{a}$ \\
\hline AIB recap & & & $-3,818$ & & & & \\
\hline \multicolumn{8}{|l|}{ Other } \\
\hline $\begin{array}{l}\text { Bailout interest } \\
\text { retrospective }\end{array}$ & & & & & & & \\
\hline $\begin{array}{l}\text { rebate } \\
\text { Fee paid on }\end{array}$ & & & & 254 & & & \\
\hline directed investments & & & & -34 & & & \\
\hline Residual & 0 & 0 & 1 & 5 & -14 & 8 & 0 \\
\hline $\begin{array}{l}\text { Net cost for } \\
\text { government }\end{array}$ & 0 & $-3,767$ & $-35,543$ & $-6,370$ & 495 & 464 & 22 \\
\hline
\end{tabular}

Source: CSO.

whether there was an expectation of a return or not. The table, however, includes the net amount of the injection into BOI in 2011 and excludes the purchase of Irish Life in 2012 because this entity was acquired with the expectation of a quick resale, which happened in 2013. The amounts reinvested into banks from non-cash dividends to the NPRF were excluded. Fees received for any of these transactions were also omitted. The table thus shows a legitimate non-statistician view of injections into the banking sector and in fact suggests a total injection of $c . € 63$ billion. 
Table 7: Capital injections into banks, Ireland, 2009-14, €m

\begin{tabular}{lcrc}
\hline Event & Year & Amount & Notes \\
\hline Preference shares, BOI, AIB & 2009 & 7,000 & 2 \\
Anglo capital injection & 2009 & 4,000 & 3 \\
Special investment shares, INBS, EBS & 2010 & 725 & 3 \\
Promissory note & 2010 & 30,850 & 3 \\
AIB recapitalisation & 2010 & 3,700 & 5 \\
July 2011 recapitalisation & 2011 & 16,567 & 6 \\
Total & & 62,842 & \\
\hline
\end{tabular}

Source: Author's calculations from CSO and Department of Finance sources.

What is the cost to the state of financing the banking sector?

The deficit and debt statistics prepared as part of the EDP provide a firm basis for measuring the effect of government transactions. In particular the classification of transactions as financial or nonfinancial is key for estimating which injections are considered remunerable and which are 'something for nothing'. The sum of deficit-impacting direct and indirect transactions is given in Table 6 and is summarised in Table 8 , showing a cost to date of $€ 44.7$ billion. This perspective of the cost of financing the banking sector excludes consideration of the opportunity cost forgone of capital injections made by the NPRF.

Table 8: Net cost (-) for general government of banking interventions, Ireland, 2008-14, $€ \mathrm{~m}$

\begin{tabular}{lrrrrrrrr}
\hline & 2008 & 2009 & 2010 & 2011 & 2012 & 2013 & 2014 & Total \\
\hline $\begin{array}{l}\text { Net cost } \\
\text { for government }\end{array}$ & 0 & $-3,766$ & $-35,543$ & $-6,370$ & 495 & 464 & 22 & $-44,699$ \\
\hline
\end{tabular}

Source: CSO.

\section{How much of Ireland's outstanding debt relates to financing of the banking sector?}

In Table 1 the impacts on the debt of direct interventions with the banking sector for the period 2008 to 2014 are given. It is noted that, by convention, flows from and into the Exchequer account impact the debt, and that flows to and from the NPRF are excluded from the calculation. The debt impacts of capital injections, the cost of interest payments and the reduction of debt by inflows to the Exchequer sum to $€ 40.4$ billion for the whole period. 
The imputed interest costs, the implied cost of the government guarantee and the increased income from the Central Bank, which are detailed in Table 6 and sum to a net cost of just over $€ 3$ billion over the period, also indirectly impact the debt.

Considering then the direct and indirect impacts, $€ 43.5$ billion is an acceptable estimate of the current amount of Ireland's debt which relates to the banking crisis. ${ }^{8}$ Ireland's debt at end-2014 is reported at $€ 203$ billion, or 110 per cent of GDP, and well above the EDP target of 60 per cent of GDP. The estimate shows that 23 percentage points of Ireland's debt ratio at end-2014 was connected to the bank interventions during the financial crisis.

\section{How much of Ireland's interest bill relates to financing of the banking sector?}

The interest bill for government, being non-discretionary, is one of the key aggregates of the fiscal statistics. As well as being a large component of the deficit, it is used in various analyses of the government finances, such as debt dynamics and the structural balance. The tables for the financial crisis show estimates of interest paid from 2008 to 2014 relating to the financial crisis and include promissory note interest, interest paid by the IBRC for the years when it was classified in government, interest on the floating rate notes since 2013, imputed interest and the implied interest cost to the state until June 2011 of the government guarantee. The share of interest payments relating to the financial crisis is illustrated in Table 9.

Table 9: Interest relating to the financial crisis, Ireland, 2008-14, $€ \mathbf{m}$

\begin{tabular}{lrrrrrrr}
\hline & 2008 & 2009 & 2010 & 2011 & 2012 & 2013 & 2014 \\
\hline Total interest & 2,398 & 3,290 & 4,921 & 5,888 & 7,157 & 7,666 & 7,502 \\
$\begin{array}{l}\text { Interest relating } \\
\text { to banking }\end{array}$ & & & & & & & \\
interventions & 110 & 651 & 1,893 & 2,142 & 1,905 & 1,715 & 1,432 \\
$\%$ of GDP & 0.1 & 0.4 & 1.1 & 1.3 & 1.1 & 1.0 & 0.8 \\
\hline
\end{tabular}

Source: CSO.

${ }^{8}$ It is noted that the answer to the total outstanding debt of $€ 43.5$ billion is close to the total cost to the state, which is $€ 44.7$ billion. In fact, although payments from the Exchequer that impact the deficit also impact the debt, this is somewhat coincidental. For example, over $€ 3.5$ billion of the deficit-worsening part of the July 2011 recapitalisation from the NPRF had no impact on the debt. 
Care should be taken when interpreting these figures. For example, in 2014 almost 1 per cent of Ireland's interest bill related to banking interventions during the crisis. However, the interest cost is currently offset by the coupon on the contingent capital notes and preference share dividend income. Furthermore, the interest paid on the floating rate notes related to the extinguishing of the promissory notes is paid to the Central Bank, which pays a dividend to the state.

\section{Conclusion}

This paper has provided a historical record of the Irish Government's interventions with the banking sector during the financial crisis. For the non-specialist it provides an exhaustive list of transactions between 2008 and 2014. It also explains the accounting treatment and implications of these transactions in the context of the deficit and debt targets set by the Stability and Growth Pact. The results in the paper suggest that the full injection into Irish banks during the crisis was $€ 63$ billion. The cost to the state is estimated to be $€ 44.7$ billion with an impact on the debt of $€ 43.5$ billion. Legacy interest costs related to the interventions were estimated at 0.8 per cent of GDP in 2014, but this was partly offset by income on shares and notes issued to capitalise the banks.

Looking forward, the expected return to the state of amounts paid out under the ELG scheme after the liquidaton of IBRC, as well as the disposals of AIB and Permanent TSB (formerly IL\&P), will eventually improve the overall impact on Ireland's debt and annual interest cost. There will, however, be loss of income with the redemption of the AIB contingent capital notes in 2016 and the likely repurchase by AIB of the preference shares. The floating rate notes used to extinguish the promissory notes will be sold to third parties on a phased basis over time. This will result in lower operating profit for the Central Bank and thus lower dividend income to the state. With the completion of these events the last transactions relating to the financial crisis will be concluded. There will remain an ongoing interest cost representing the cost to the state of financing the bailout.

\section{Buíochas}

Tá mo bhuíochas ag dul do mo chomhghleacaithe sa Phríomh-Oifig Staidrimh, go háirithe Gillian Roche agus Ciaran Judge, agus m'iarchomhghleacaithe sa Roinn Airgeadais. 


\section{Disclaimer}

The author is a senior statistician in the CSO. The views expressed in this article are those of the author and not those of the CSO.

\section{References}

Barnes, S., \& Smyth, D. (2013). The government's balance sheet after the crisis: A comprehensive perspective. Retrieved from www.fiscalcouncil.ie [26 April 2014].

Central Bank of Ireland. (2011). Financial measures programme - executive summary. Central Bank Quarterly Bulletin Q2, 69-76.

Central Bank of Ireland. (2014). Annual report 2014. Dublin: Central Bank.

CSO. (2014a). National income and expenditure annual results 2013. Cork: CSO.

CSO. (2014b). Government finance statistics quarterly results, quarter 12014. Cork: CSO.

CSO. (2015). Quarterly national accounts, quarter 4 2014. Cork: CSO.

Cussen, M., \& Lucey, M. (2011). Treatment of special bank interventions in Irish government statistics. Central Bank Quarterly Bulletin Q4, 78-92.

Dáil Éireann. (2012). Written answers: Fiscal policy. 8 May. Dáil Debates, 764 (3).

Department of Finance. (2012). Medium term fiscal statement. Dublin: Department of Finance.

European Commission. (2010). Report on Greek Government deficit and debt statistics. Brussels: European Commission.

European Commission. (2013). European system of accounts, 2010. Luxembourg: Publications Office of the European Union.

European Commission. (2014). Manual on government deficit and debt, implementation of ESA 2010 (2014 ed.). Luxembourg: Publications Office of the European Union.

European Communities, International Monetary Fund, OECD, UN and World Bank. (2009). System of national accounts 2008. Retrieved from unstats.un.org/unsd/nationalaccount/docs/SNA2008.pdf [9 April 2015].

Eurostat. (2009a). The impact of bank recapitalisations on government finance statistics during the financial crisis. Retrieved from ec.europa.eu [9 April 2015].

Eurostat. (2009b). Preliminary view on the ESA95 accounting treatment of the National Asset Management Agency (NAMA) and related majority privately owned SPV. Retrieved from ec.europa.eu [9 April 2015].

Eurostat. (2010). Preliminary view on the ESA95 accounting treatment of time of recording of interest payments on the promissory notes payable to Anglo Irish Bank. Retrieved from ec.europa.eu [9 April 2015].

Eurostat. (2012a). ESA95 accounting treatment of July 2011 capital injections into Irish banks. Annex 2: Methodological note to Eurostat. Retrieved from ec.europa.eu [9 April 2015]. 
Eurostat. (2012b). The impact of bank recapitalisations on government finance statistics during the financial crisis. Retrieved from ec.europa.eu [9 April 2015].

Eurostat. (2013a). Final findings, EDP dialogue visit to Ireland, 30-31 August 2012. Retrieved from ec.europa.eu [9 April 2015].

Eurostat. (2013b). Clarification of the criteria to be taken into account for the recording of government capital injections into banks. Retrieved from ec.europa.eu [9 April 2015].

Eurostat. (2014). Classification of Irish Bank Resolution Corporation (IBRC) under ESA2010. Retrieved from ec.europa.eu [9 April 2015].

Government of Ireland. (2010). Finance accounts: Audited financial statements of the Exchequer for the financial year 1 January 2010 to 31 December 2010. Dublin: The Stationery Office.

McArdle, P. (2012). The euro crisis: Refinancing the Irish bailout - the options post the June 2012 summit. Retrieved from www.iiea.com [9 April 2015].

National Treasury Management Agency. (2014). Annual report and accounts for the year ended 31 December 2013. Dublin: National Treasury Management Agency.

NPRF. (2010). Annual report and financial statements. Dublin: NPRF. 